\title{
Menthol Modulates Pacemaker Potentials through TRPA1 Channels in Cultured Interstitial Cells of Cajal from Murine Small Intestine
}

\author{
Hyun Jung Kima,b Jinhong Wiec Insuk Soc Myeong Ho Jung ${ }^{a, b}$ Ki-Tae Hab \\ Byung Joo Kima,b \\ aDivision of Longevity and Biofunctional Medicine and 'Healthy Aging Korean Medical Research Center, \\ Pusan National University School of Korean Medicine, Yangsan, 'Department of Physiology, Seoul \\ National University College of Medicine, Seoul, Republic of Korea
}

\section{Key Words}

Interstitial Cells of Cajal - Menthol - Gastrointestinal Tract - Transient Receptor Potential Channel • TRP Channel

\begin{abstract}
Background/Aims: ICCs are the pacemaker cells responsible for slow waves in gastrointestinal (GI) smooth muscle, and generate periodic pacemaker potentials in current-clamp mode. Methods: The effects of menthol on the pacemaker potentials of cultured interstitial cells of Cajal (ICCs) from mouse small intestine were studied using the whole cell patch clamp technique. Results: Menthol $(1-10 \mu \mathrm{M})$ was found to induce membrane potential depolarization in a concentration-dependent manner. The effects of various TRP channel antagonists were examined to investigate the receptors involved. The addition of the TRPM8 antagonist, AMTB, did not block menthol-induced membrane potential depolarizations, but TRPA1 antagonists (A967079 or HC-030031) blocked the effects of menthol, as did intracellular $\mathrm{GDP}_{\beta} \mathrm{S}$. Furthermore, external and internal $\mathrm{Ca}^{2+}$ levels were found to depolarize menthol-induced membrane potentials, whereas external $\mathrm{Na}^{+}$was not. Y-27632 (a Rho kinase inhibitor), SC-560 (a selective COX 1 inhibitor), NS-398 (a selective COX 2 inhibitor), ozagrel (a thromboxane A2 synthase inhibitor) and SQ-29548 (highly selective thromboxane receptor antagonist) were used to investigate the involvements of Rho-kinase, cyclooxygenase (COX), and the thromboxane pathway in menthol-induced membrane potential depolarizations, and all inhibitors were found to block the effect of menthol. Conclusions: These results suggest that menthol-induced membrane potential depolarizations occur in a G-protein-, $\mathrm{Ca}^{2+}{ }_{-}$, $\mathrm{Rho}^{-}$ kinase-, COX-, and thromboxane $\mathrm{A}_{2}$-dependent manner via TRPA1 receptor in cultured ICCs in murine small intestine. The study shows ICCs are targeted by menthol and that this interaction can affect intestinal motility.




\section{Introduction}

Menthol (2-isopropyl-5-methyl-cyclohexanol) is an organic compound found in mint, and is widely used in the food, beverage, and cosmetic industries and as a treatment for various diseases $[1,2]$. Menthol is a primary activator of the cold and menthol-sensitive transient receptor potential melastatin 8 (TRPM8) channel [3] and of TRP-ankyrin 1 (TRPA1) channel [4]. TRPM8 channels have been detected in dorsal root ganglia, vagal afferent neurons, and in the gut $[3,5,6]$, and TRPA 1 channels in enteric neurons and enteroendocrine cells $[7,8]$. Although, enteric-coated peppermint formulations are used to treat vomiting [9, $10]$, dyspepsia, and irritable bowel syndrome $[11,12]$, the cellular and molecular targets of menthol that mediate its effects in gastrointestinal (GI) motility disorders have not been determined.

Interstitial cells of Cajal (ICCs) are the pacemaker cells of the GI tract [13-15] and participate in the generation, coordination, and propagation of electrical slow wave activity, the transduction of motor neural inputs from the enteric nervous system, and in the mechanosensation of smooth muscle cells [16-18]. C-kit [19] and anoctamin-1 (ANO1) [20] are expressed in ICCs and a selective molecular marker for all classes of ICCs in the human and mouse GI tract. In addition, it has been shown that the pacemaker activities of ICCs in the murine small intestine are mainly due to periodic activations of nonselective cation channels (NSCCs) [21, 22] or $\mathrm{Cl}^{-}$channels [23, 24]. Kim et al. [25] suggested transient receptor potential melastatin (TRPM) 7 is required for ICC pacemaker activity in the murine small intestine, and that a $\mathrm{Ca}^{2+}$-activated $\mathrm{Cl}^{-}$channel (CaCC) is involved in the slow waves generated by ICCs; this $\mathrm{Cl}^{-}$channel was later identified as transmembrane protein $16 \mathrm{~A}$ (Tmem16A; AN01) [24]. The role played by ANO1 in ICC pacemaker activity was identified in ANO1 knockout mice [26], and several other authors have shown that ANO1 participates in pacemaker activity [27]. Accordingly, it has been proposed that TRPM7 and ANO1 is responsible for the pacemaker activity in ICCs and may be considered the potential targets for the pharmacological treatment of GI motility disorders. The absence of ICCs in GI tract causes abnormally slow electrical waves and reduces smooth muscle cell contractility and intestinal transit [25] and ICCs also mediate or transduce inputs from the enteric nervous system [28]. Therefore, ICCs play an important role in the determination and regulation of GI motility.

The effect of menthol on pacemaker activity, receptor subtypes and signal transduction pathways in ICCs remains to be defined. Therefore, experiments were performed to determine whether menthol modulates pacemaker activities, to identify its receptor type and to determine specific signal transduction mechanisms in cultured ICCs from murine small intestine.

\section{Materials and Methods}

\section{Preparation of cells and cell cultures}

Animal care and experiments on animals were conducted in accordance with the guidelines issued by the ethics committee of Pusan National University (Busan, Republic of Korea; Approval no. PNU-2015-1036). Balb/c mice were used in the studies. In each mouse, the small intestine was removed (from $1 \mathrm{~cm}$ below the pyloric ring to the cecum) and opened along the mesenteric border. Luminal contents were washed using Krebs-Ringer bicarbonate solution, and the tissues obtained were pinned to the base of a Sylgard dish. Mucosa was removed by sharp dissection. Small tissue strips of intestine muscle (consisting of both circular and longitudinal muscles) were equilibrated in nominally $\mathrm{Ca}^{2+}$ free solution (containing, in $\mathrm{mM}: \mathrm{KCl}$ 5.36, $\mathrm{NaCl} 125, \mathrm{NaOH} \mathrm{0.34}, \mathrm{Na}_{2} \mathrm{HCO}_{3} 0.44$, glucose 10, sucrose 2.9, and HEPES 11 (pH 7.4) for 30 min. Cells were then dispersed in an enzyme solution containing collagenase (Worthington Biochemical, Lakewood, NJ, USA, $1.3 \mathrm{mg} \mathrm{ml}^{-1}$ ), bovine serum albumin (BSA, Sigma-Aldrich, St Louis, MO, $2 \mathrm{mg} \mathrm{ml}^{-1}$ ), trypsin inhibitor (Sigma-Aldrich, $2 \mathrm{mg} \mathrm{ml}^{-1}$ ), and ATP magnesium salt $\left(0.27 \mathrm{mg} \mathrm{ml}^{-1}\right)$. Cells were then plated onto sterile

\section{KARGER}




\section{Cellular Physiology Cell Physiol Biochem 2016;38:1869-1882

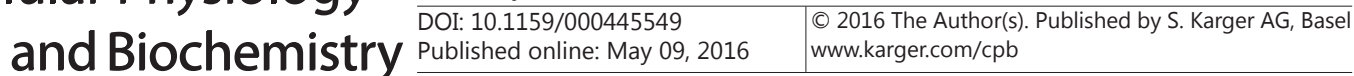 \\ Kim et al.: Effects of Menthol in ICCs}

glass coverslips coated with murine collagen $\left(2.5 \mathrm{\mu g} \mathrm{ml}^{-1}\right.$; Falcon/BD, Franklin Lakes, NJ, USA $)$ in a $35 \mathrm{~mm}$ culture dish, and cultured at $37^{\circ} \mathrm{C}$ in a $95 \% \mathrm{O}_{2}-5 \% \mathrm{CO}_{2}$ incubator in smooth muscle growth medium (SMGM; Clonetics, San Diego, CA) supplemented with $2 \%$ antibiotics/antimycotics (Gibco, Grand Island, NY) and murine stem cell factor (SCF; $5 \mathrm{ng} \mathrm{ml}^{-1}$; Sigma-Aldrich). ICCs were identified immunologically using anti-ckit antibody (Santa cruz, Dallas, TX) at a dilution of 1:50 for $20 \mathrm{~min}$ [29]. ICCs were morphologically distinct from other cell types in culture, and were identified by phase contrast microscopy after being verified with anti-c-kit antibody.

\section{Patch-clamp experiments}

The physiological salt solution used to bathe cultured ICC cells ( $\mathrm{Na}^{+}$-Tyrode) contained (in $\mathrm{mM}$ ): $\mathrm{KCl} 5, \mathrm{NaCl} 135, \mathrm{CaCl}_{2}$ 2, glucose $10, \mathrm{MgCl}_{2} 1.2$, and HEPES 10, adjusted to $\mathrm{pH} 7.4$ with $\mathrm{NaOH}$. The pipette solution used to examine pacemaking activity contained (in mM): $\mathrm{KCl} 140, \mathrm{MgCl}_{2} 5, \mathrm{~K}_{2} \mathrm{ATP} 2.7, \mathrm{Na}_{3} \mathrm{GTP} 0.1$, creatine phosphate disodium 2.5, HEPES 5, and EGTA 0.1 (adjusted to pH 7.2 with $\mathrm{KOH}$; The final pipette $\mathrm{K}^{+}$ concentration is $145.4 \mathrm{mM}$ ). Patch-clamp techniques were conducted in whole-cell configuration to record membrane potentials (current clamp) of cultured ICCs using Axopatch I-D and Axopatch 200B amplifiers (Axon Instruments, Foster, CA). We did not inject any current to record the resting membrane potential at current-clamp mode. Pipette resistance was usually around 4-5 megaohm and series resistance (or access resistance at Axon instrument) was around 10 megaohm. The acquisition frequency was around $2000 \mathrm{~Hz}$. Command pulses were applied using an IBM-compatible personal computer and pClamp software (version 6.1 and version 10.0; Axon Instruments). Data were filtered at $5 \mathrm{kHz}$ and displayed on an oscilloscope, a computer monitor, and/or a pen recorder (Gould 2200; Gould, Valley View, OH, USA). Results were analyzed using pClamp and Origin software (version 6.0, Microcal, USA). All experiments were performed at $30-33^{\circ} \mathrm{C}$.

\section{Immunohistochemistry}

Cultured ICCs from the small intestines of Balb/C mice were fixed in cold acetone $\left(4^{\circ} \mathrm{C}\right)$ for $5 \mathrm{~min}$, washed in phosphate-buffered saline (PBS; $0.01 \mathrm{M}, \mathrm{pH} 7.4$ ), and immersed in $0.3 \%$ Triton X-100 in PBS. After blocking with $1 \%$ BSA in $0.01 \mathrm{M}$ PBS for 1 hour at room temperature $\left(22-24^{\circ} \mathrm{C}\right)$, cells were incubated with a rat monoclonal antibody raised against c-Kit (Santa cruze; SC-168) or ANO1 (Santa cruze; SC-135235) at $0.5 \mu \mathrm{g} / \mathrm{ml}$ or with a rabbit polyclonal antibody against TRPA1 (Santa cruze; SC-32351) in PBS for 24 hours $\left(4^{\circ} \mathrm{C}\right)$. After rinsing in PBS at $4^{\circ} \mathrm{C}$, cells were labeled with fluorescein isothiocyanate (FITC)-coupled donkey anti-rabbit IgG secondary antibody (1:100; Jackson Immunoresearch Laboratories, Bar Harbor, MN, U.S.A.) or Texas red-conjugated donkey anti-rat IgG (1:100, Jackson Immunoresearch Laboratories) for 1 hour at room temperature. For double immunostaining, specimens were incubated with a mixture of antibodies raised against TRPA 1 and antibody raised against c-kit for $24 \mathrm{~h}$ at $4^{\circ} \mathrm{C}$. After thorough washing with PBS, the mixture of labeled secondary antibodies was incubated for 1 hour at room temperature. Cells were examined under an FV 300 laser scanning confocal microscope (Olympus, Tokyo) at an excitation/emission wavelength appropriate for FITC (495/525 nm) or Texas red (590/615 nm). Final images were constructed using Flow-View software (Olympus).

Drugs

WS-12, Y-27632, NS-398, and ozagrel were purchased from TOCRIS (Minneapolis, MN, USA). SQ-29548 was obtained from Cayman (Ann Arbor, MI, USA). All other drugs were obtained from Sigma-Aldrich (St. Louis, MO). Stock solutions were prepared and stored, according to manufacturers' instructions. Chemicals were dissolved in $\mathrm{Na}^{+}$-Tyrode solution to their final concentrations immediately before use. For application of drugs, the bath chamber was superfused by gravity at a rate of $\sim 2-3 \mathrm{ml} / \mathrm{min}$ constantly.

\section{Statistical analysis}

Results are expressed as means \pm standard errors. Normality test was performed for all variables. The significances of differences between results were evaluated using the Student's unpaired $t$-test. $P$-values of $<0.05$ were deemed significant. The $n$ values reported in the text refer to the number of cells used in patchclamp experiments.

\section{KARGER}




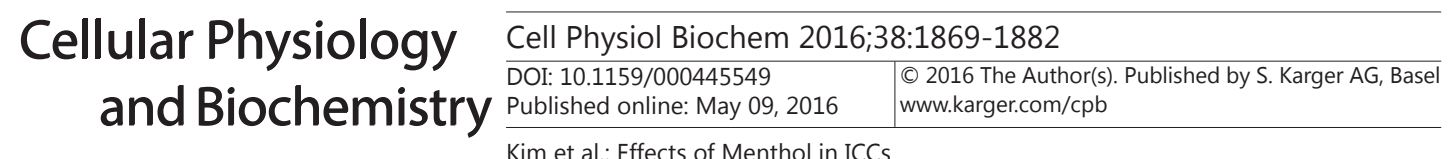

\section{Results}

Effects of menthol on the pacemaker potentials of cultured ICC clusters

In current clamp mode, cells in cultured ICC clusters had a mean resting membrane potential of $-57.3 \pm 2.2 \mathrm{mV}$ and produced pacemaker potentials (PPs) of amplitude $24.5 \pm 3.2$ $\mathrm{mV}(\mathrm{n}=62)$ at $30^{\circ} \mathrm{C}$. Initially, we examined the effects of menthol on PPs. Menthol $(1,5$ or $10 \mu \mathrm{M})$ elicited membrane potential depolarizations in a concentration-dependent manner (Fig. 1A-1C); mean depolarizations were $0 \mathrm{mV}$ at $0.03 \mu \mathrm{M}(\mathrm{n}=5), 1.0 \pm 0.1 \mathrm{mV}$ at $0.1 \mu \mathrm{M}(\mathrm{n}=$ 5), $3.5 \pm 0.2 \mathrm{mV}$ at $0.3 \mu \mathrm{M}(\mathrm{n}=6), 9.2 \pm 0.9 \mathrm{mV}$ at $1 \mu \mathrm{M}(\mathrm{n}=6), 11.5 \pm 0.8 \mathrm{mV}$ at $3 \mu \mathrm{M}(\mathrm{n}=5)$, $13.4 \pm 1.3 \mathrm{mV}$ at $5 \mu \mathrm{M}(\mathrm{n}=6), 26.3 \pm 1.5 \mathrm{mV}$ at $10 \mu \mathrm{M}, 52.1 \pm 2.1 \mathrm{mV}$ at $100 \mu \mathrm{M}(\mathrm{n}=5)$, and $57.3 \pm 3.5 \mathrm{mV}$ at $1 \mathrm{mM}(\mathrm{n}=5)$ (Fig. 1D). These results showed menthol induced membrane potential depolarization in a concentration-dependent manner.

TRPA1 receptor was involved in menthol-induced membrane potential depolarization

Menthol has been reported to be a specific activator of TRPM8 $[3,30]$ and of TRPA1 [4]; both members of the TRP family. Therefore, we investigated the effects of TRPM8 and TRPA1 antagonists on membrane potential depolarization by menthol. Pretreatment with a TRPM8 antagonist (AMTB; (N- (3-aminopropyl)- 2- \{[(3-methylphenyl) methyl $]$ oxy\}- N - (2-thienylmethyl)benzamide hydrochloride salt [31]) at $10 \mu \mathrm{M}$ for $5 \mathrm{~min}$ did not block menthol $(10 \mu \mathrm{M})$-induced membrane potential depolarization but reduce latency for recovery (Fig. 2A). However, pretreatment with a TRPA1 antagonist (A967079 $10 \mu \mathrm{M}$ or HC$03003130 \mu \mathrm{M}$ ) for 5 min blocked depolarization (Figs. 2B and 2C). Mean depolarizations were $26.1 \pm 0.8 \mathrm{mV}$ for AMTB $(\mathrm{n}=6), 0.8 \pm 0.5 \mathrm{mV}$ for A967079 $(\mathrm{n}=7)$ and $0.5 \pm 0.4 \mathrm{mV}$ for HC-030031 (n = 7; Fig. 2D). Furthermore, a TRPM8 agonist (WS-12 $100 \mu \mathrm{M}$ ) had no effect on PPs (Fig. 3A) but that a TRPA1 agonist (Allyl isothiocyanate (AITC) $100 \mu \mathrm{M}$ and cinnamaldehyde (CMA) $100 \mu \mathrm{M}$ ) depolarized PPs (Fig. 3B and 3C). Mean depolarization was $0.5 \pm 0.4 \mathrm{mV}$ for WS-12 ( $\mathrm{n}=5), 24.6 \pm 1.5 \mathrm{mV}$ for AITC $(\mathrm{n}=6)$ ), and $25.1 \pm 1.7 \mathrm{mV}$ for CMA ( $=6$; Fig. 3D). In addition, we checked for the presence of TRPA1 channels by immunolabeling cultured ICCs. The co-localizations of c-kit (red) or ANO1 (red) and TRPA1 channels (green) in ICCs produced a yellow color (merge) (Fig. 4). Double labeling of ICCs from murine small intestine showed that these proteins were localized in ICCs. These results suggest menthol functions in ICCs via TRPA1 channels.

Fig. 1. Effects of menthol on pacemaker potentials in cultured ICCs from murine small intestine. (A-C) Pacemaker potentials of ICCs exposed to menthol $(1-10 \mu \mathrm{M})$ in current-clamp mode $(\mathrm{I}=0)$. Menthol depolarized pacemaker potentials in a concentration-dependent manner. Responses to menthol are summarized in (D). Concentration-response curve with various menthol concentrations $(0.03,0.1,0.3,1,3,10$, $100 \mu \mathrm{M}$ and $1 \mathrm{mM}$ ) represents mean values \pm SEs. ${ }^{*} P<$ 0.05 , ${ }^{* *} P<0.01$ : significantly different from non-treated controls.

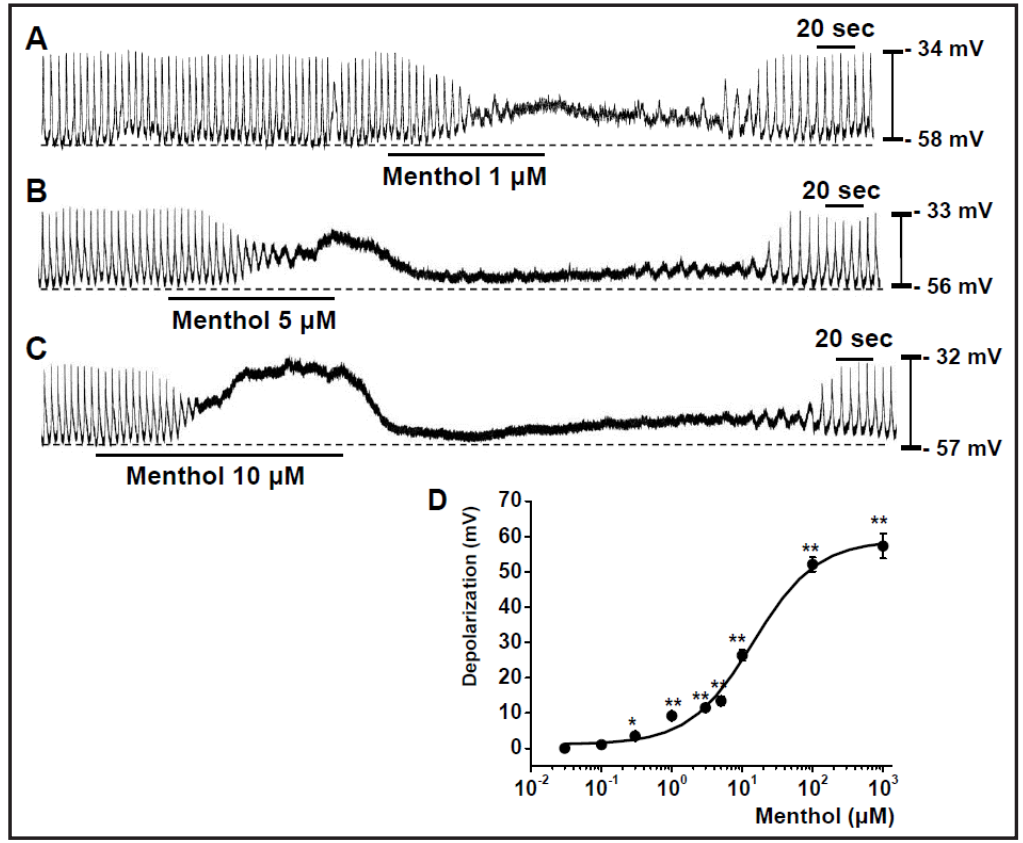


Fig. 2. Effects of TRP channel antagonists on menthol-induced pacemaker potential depolarizations in cultured ICCs. (A) Pretreatment with a TRPM8 antagonist (AMTB) for $5 \mathrm{~min}$ did not block menthol-induced pacemaker potential depolarization. $(\mathrm{B}, \mathrm{C})$ However, pretreatment with TRPA1 antagonists (A967079 or HC-030031) blocked menthol-induced pacemaker potential depolarization. (D) A summary of responses to TRP channel antagonists. Bars represent mean values \pm SEs. ${ }^{* *} P<0.01$ : significantly different from non-treated controls.

Fig. 3. Effects of TRP channel agonists on pacemaker potentials in cultured ICCs from murine small intestine. (A) Null effect of WS-12 (TRPM8 agonist) on pacemaker potentials. (B and C) Depolarizing effects of AITC and CMA (TRPA1 agonist) on pacemaker potentials. (D) Responses to TRP channel agonists are summarized. Bars represent mean values \pm SEs. ** $P<0.01$ : significantly different from the control. AITC: Allyl isothiocyanate. CMA: cinnamaldehyde.
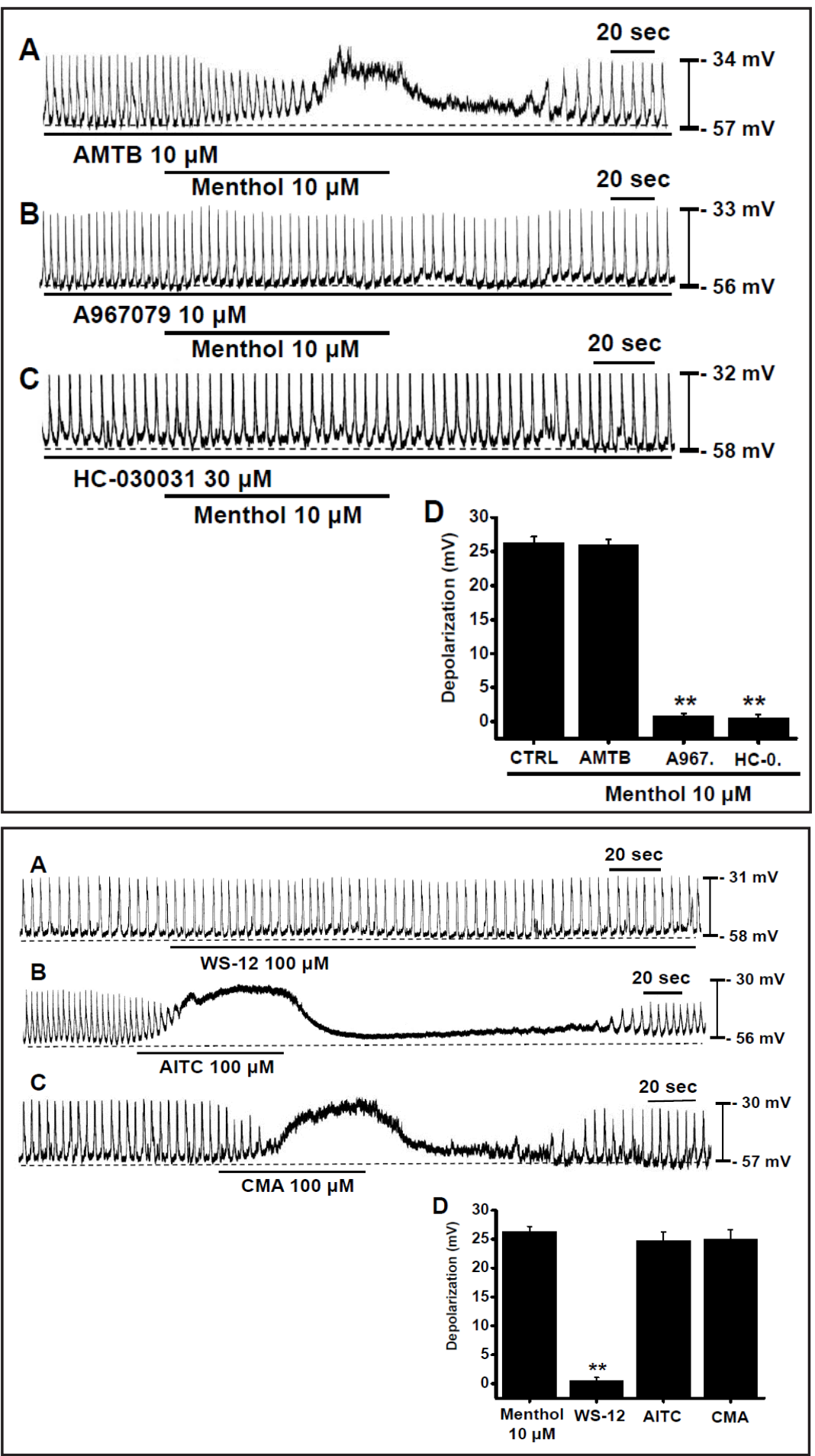

Effects of $G$ proteins on menthol-induced membrane potential depolarization

To investigate the involvement of $\mathrm{G}$ proteins during menthol-induced membrane potential depolarizations, we applied $\mathrm{GDP}_{\beta} \mathrm{S}$ (a non-hydrolysable guanosine $5^{\prime}$-diphosphate analogue, which permanently inactivates $G$-protein binding proteins [32, 33]), using patch pipettes. When $\mathrm{GDP}_{\beta} \mathrm{S}(1 \mathrm{mM})$ was in the pipette solution, menthol-induced depolarizations were lower than under GDP ${ }_{\beta} S$-free conditions $(n=5$; Fig. 5A). Mean depolarizations were $5.8 \pm 1.0 \mathrm{mV}$ in the presence of $\mathrm{GDP}_{\beta} \mathrm{S}$ and $78.1 \%$ was reduced (Fig. 5B). These results

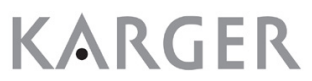




\section{Cellular Physiology Cell Physiol Biochem 2016;38:1869-1882 \begin{tabular}{ll|l} 
DOI: 10.1159/000445549 & $\begin{array}{l}\text { O 2016 The Author(s). Published by S. Karger AG, Basel } \\
\text { www.karger.com/cpb }\end{array}$
\end{tabular}

Fig. 4. Expressions of TRPA1 proteins in cultured ICCs. Double-labeling of cultured ICCs with TRPA1 (green) and c-kit (red; A) or ANO1 (red; B) antibodies. Cultured ICCs demonstrated TRPA1 and c-kit or ANO1 co-localization, as indicated by the yellow color (arrows). Scale bars $=10 \mu \mathrm{m}$.
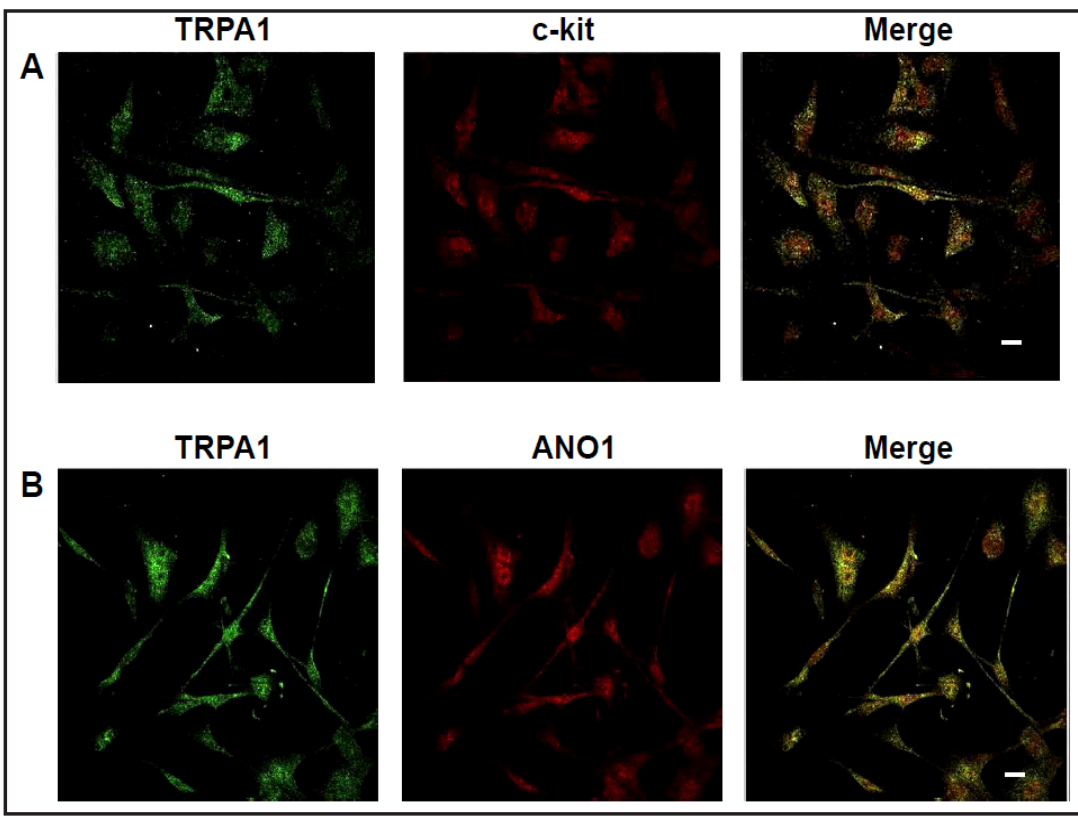

Fig. 5. Effects of GDP ${ }_{\beta} S$ in the pipette on menthol-induced pacemaker potential depolarizations in cultured ICCs. (A) Pacemaking activities of ICCs exposed to menthol in the presence of $\mathrm{GDP}_{\beta} \mathrm{S}(1 \mathrm{mM})$ in the pipette. Under these conditions, menthol caused slight depolarization. (B) Response to menthol in the presence of $\mathrm{GDP}_{\beta} \mathrm{S}$ in the pipette. Bars represent mean values \pm SEs. ${ }^{* *} P<0.01$ : significantly different from non-treated controls.

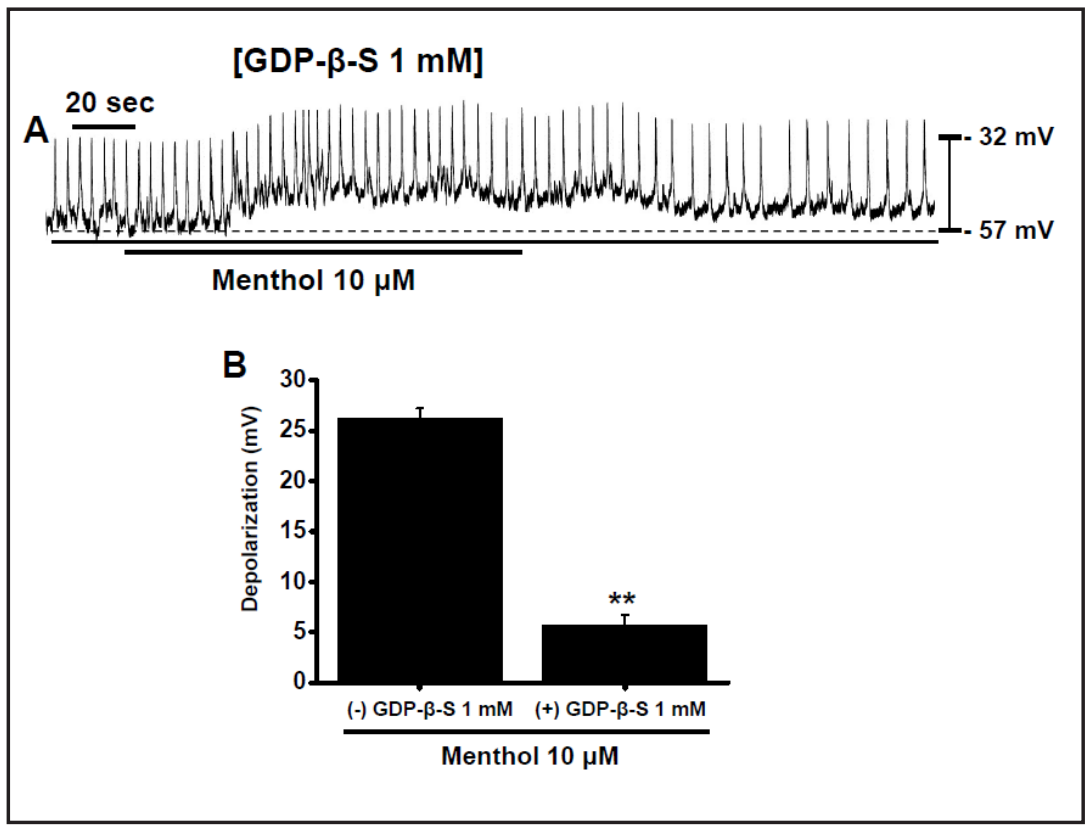

suggest that G-protein stimulation is required for menthol-induced membrane potential depolarization.

Effects of external $\mathrm{Ca}^{2+}$-free solution and of $\mathrm{Ca}^{2+}$-ATPase inhibitor in endoplasmic reticulum on the menthol-induced membrane potential depolarization

External $\mathrm{Ca}^{2+}$ influx and intracellular $\mathrm{Ca}^{2+}$ oscillations are required to generate PPs by ICCs [34]. To study the roles of external and internal $\mathrm{Ca}^{2+}$, the effects of menthol were investigated under external $\mathrm{Ca}^{2+}$-free conditions and in the presence of thapsigargin (an inhibitor of $\mathrm{Ca}^{2+}$ ATPase in endoplasmic reticulum $[35,36])$. In the presence of an external $\mathrm{Ca}^{2+}$-free solution, pacemaking activity was completely abolished, and menthol did not depolarize PPs ( $\mathrm{n}=7$; Fig. 6A). In addition, in the presence of thapsigargin, pacemaking activity was also completely abolished and menthol did not depolarize PPs ( $n=7$; Fig. 6B). Mean depolarizations were $0.6 \pm 0.5 \mathrm{mV}$ for external $\mathrm{Ca}^{2+}$-free solutions, and $0.4 \pm 0.5 \mathrm{mV}$ for thapsigargin (Fig. 6C).

\section{KARGER}


Fig. 6. Effects of an external $\mathrm{Ca}^{2+}$-free solution and of thapsigargin (a $\mathrm{Ca}^{2+}$-ATPase inhibitor in endoplasmic reticulum) on menthol-induced pacemaker potential depolarizations in cultured ICCs. (A) External $\mathrm{Ca}^{2+}$-free solution abolished the generation of pacemaker potentials, and blocked menthol-induced pacemaker potential depolarization. (B) Thapsigargin abolished pacemaker potentials and also blocked menthol-induced depolarization. (C) Responses to menthol in external $\mathrm{Ca}^{2+}$-free solution and in the presence of thapsigargin are summarized. Bars represent mean values \pm SEs. ${ }^{* *} P<0.01$ : significantly different from non-treated controls.

Fig. 7. Effects of voltage-dependent $\mathrm{Na}^{+}$channel and $\mathrm{Na}^{+}$free external solution on menthol-induced pacemaker potential depolarizations in cultured ICCs. (A) Tetrodotoxin (TTX; a voltage-dependent $\mathrm{Na}^{+}$channel blocker) had no effect on pacemaker potentials, and in the presence of TTX, menthol induced pacemaker potential depolarization. (B) Under the $\mathrm{Na}^{+}$-free external solution condition, pacemaker potentials were abolished, and under this condition, menthol induced pacemaker potential depolarization. (C) Responses to menthol in TTX and in external $\mathrm{Na}^{+}$-free solution are summarized. Bars represent mean values \pm SEs.
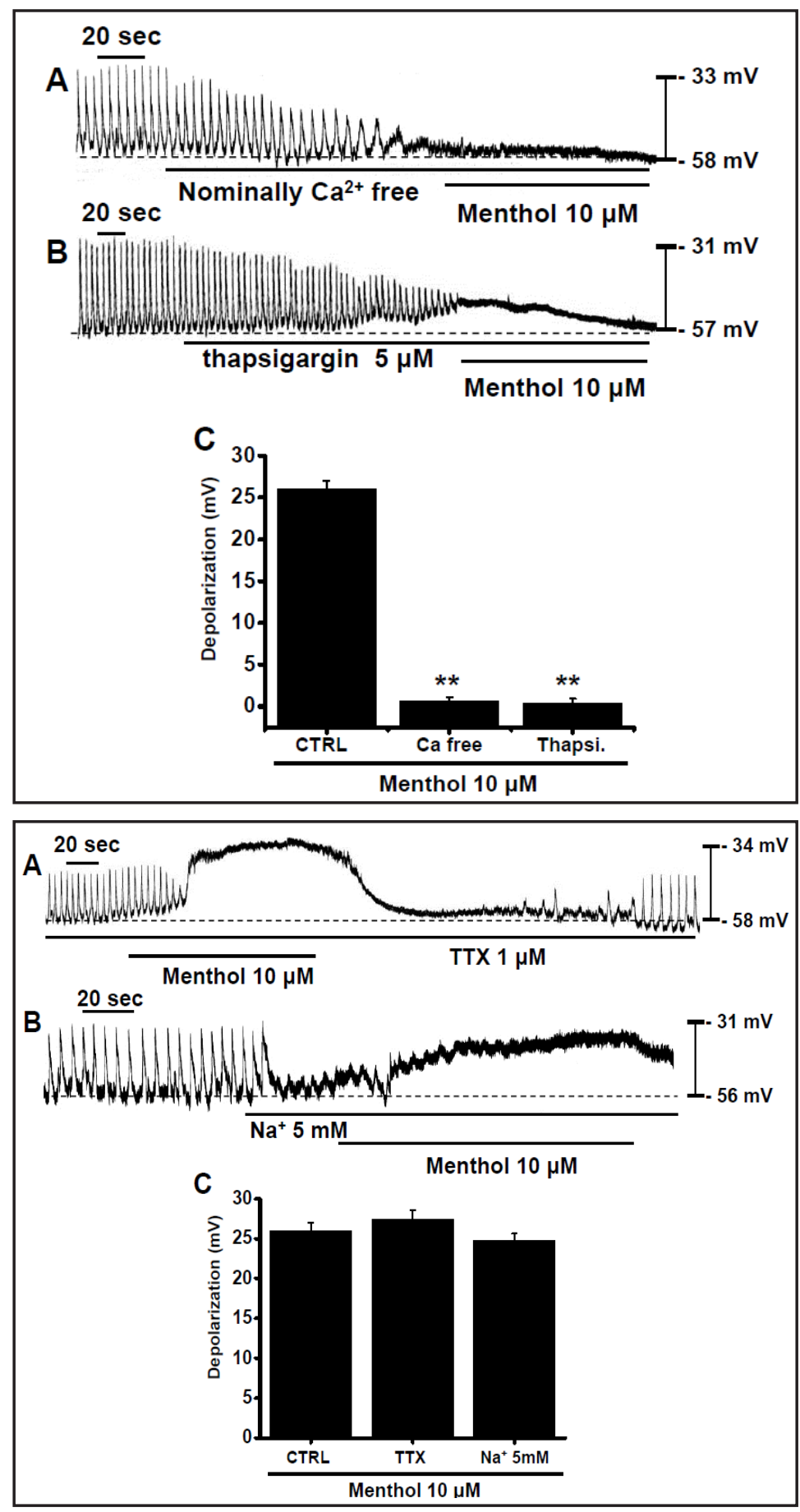

These results suggest that both external $\mathrm{Ca}^{2+}$ and $\mathrm{Ca}^{2+}$ release from intracellular stores are responsible for menthol-induced membrane potential depolarization.

Effects of voltage-dependent $\mathrm{Na}^{+}$channel and $\mathrm{Na}^{+} 5 \mathrm{mM}$ external solution on mentholinduced membrane potential depolarization

To examine the characteristics of the PPs produced by menthol, we examined the effects of a voltage-dependent $\mathrm{Na}^{+}$channel blocker and of an external $\mathrm{Na}^{+} 5 \mathrm{mM}$ solution. To identify the involvement of a voltage-dependent $\mathrm{Na}^{+}$channel mediating menthol-induced PPs, we examined the effects of tetrodotoxin (TTX; a voltage-dependent $\mathrm{Na}^{+}$channel blocker). 


\section{Cellular Physiology Cell Physiol Biochem 2016;38:1869-1882 and Biochemistry Published online: May 09, $2016 \quad \begin{aligned} & \text { DOI: 10.1159/000445549 } 2016 \text { The Author(s). Published by S. Karger AG, Basel } \\ & \text { www.karger.com/cpb }\end{aligned}$ \\ Kim et al.: Effects of Menthol in ICCs}

Fig. 8. Effects of Y-27632, SC560, NS-398, ozagrel, and SQ29548 on menthol-induced pacemaker potential depolarizations in cultured ICCs. Menthol-induced pacemaker potential depolarizations in ICCs were blocked by: (A) Y-27632 (a Rho-kinase inhibitor); (B) SC-560 (a selective COX 1 inhibitor); (C) NS-398 (a selective COX 2 inhibitor); (D) ozagrel (a thromboxane A2 synthase inhibitor); and (E) SQ-29548 (a highly selective thromboxane receptor antagonist). (F) Summarizes responses to menthol in the presence of $\mathrm{Y}-27632$, SC-560, NS-398, ozagrel, or SQ29548. Bars represent mean values \pm SEs. ${ }^{* *} P<0.01$ : significantly different from non-treated controls.

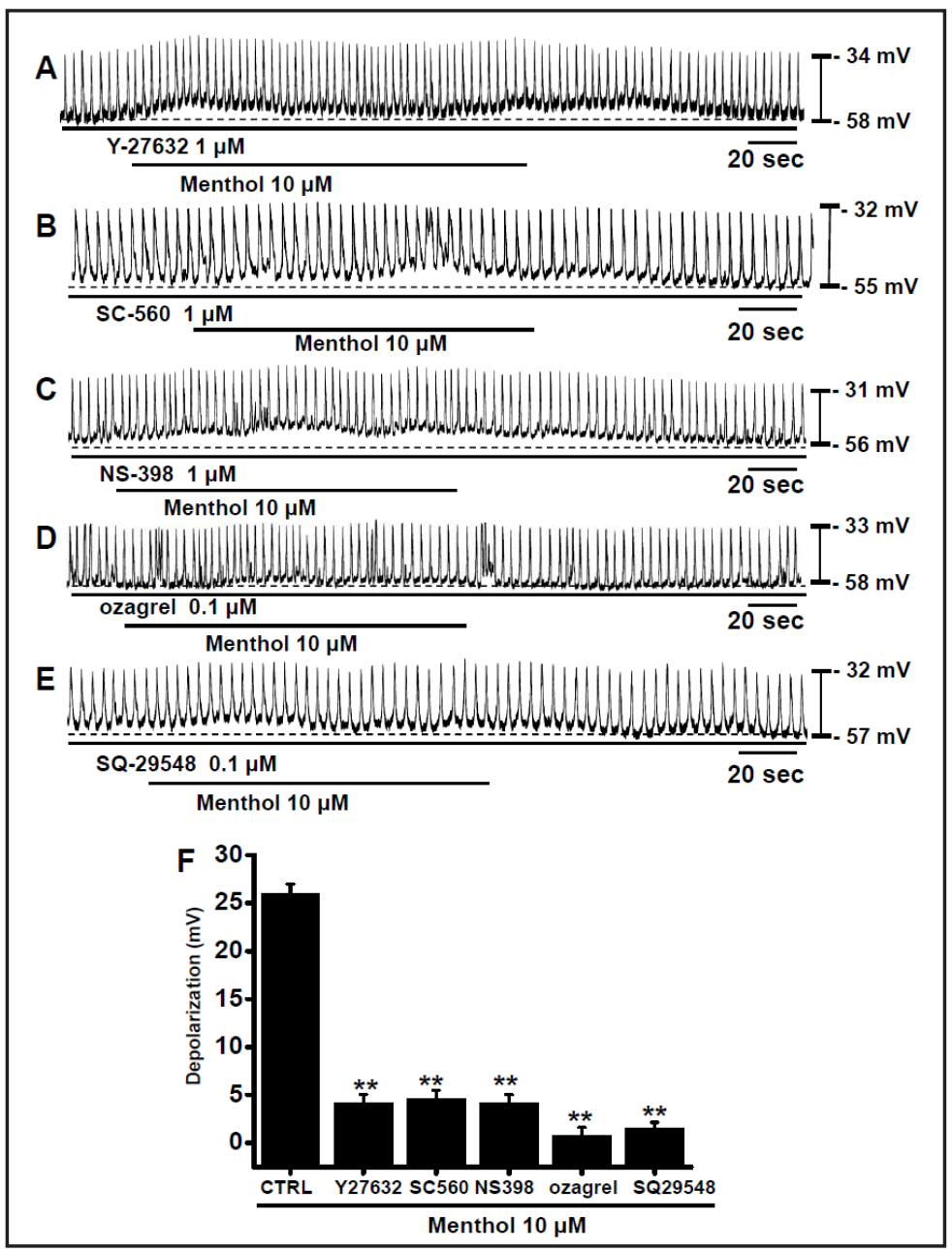

TTX $(1 \mu \mathrm{M})$ had no effect on PPs and under these conditions, menthol induced membrane potential depolarization (Fig. 7A). In the presence of external $\mathrm{Na}^{+} 5 \mathrm{mM}$ solution (prepared by replacing external $\mathrm{Na}^{+}$by the same concentration of $\mathrm{N}$-methyl-D-glucamine (NMDG)), PPs were abolished, and under these conditions, menthol $(10 \mu \mathrm{M})$ induced membrane potential depolarization (Fig. 7B). Mean depolarizations were 27.4 $\pm 1.1 \mathrm{mV}(\mathrm{n}=4)$ for TTX and 24.8 $\pm 0.8 \mathrm{mV}(\mathrm{n}=5)$ for external $\mathrm{Na}^{+} 5 \mathrm{mM}$ solution (Fig. 7C). These results suggest that external $\mathrm{Na}^{+}$is not an important driver of menthol-induced membrane potential depolarization.

Effects of Rho-kinase, cyclooxygenase, and thromboxane A2 inhibitors on menthol-induced membrane potential depolarization

Because TRPA1 can activate Rho-associated protein kinase (Rho-kinase) [37] and Rhokinase can modulate smooth muscle contraction [38], we investigated whether the Rhokinase pathway is required for menthol-induced membrane potential depolarization by measuring menthol-induced membrane potential depolarizations in the presence of Y-27632 (a Rho kinase inhibitor [37]). It was found that in the presence of Y-27632, menthol did not depolarize PPs (Fig. 8A). We also investigated the effects of a COX inhibitor and thromboxane inhibitor on menthol-induced membrane potential depolarization, because COX products have been shown to be involved in TRPA1-mediated signaling $[39,40]$. In the presence of SC-560 (a selective COX 1 inhibitor [41]), NS-398 (a selective COX 2 inhibitor [41]), ozagrel (a thromboxane A2 synthase inhibitor [42]), or SQ-29548 (a highly selective thromboxane receptor antagonist [43]), blocked menthol-induced membrane potential depolarization (n = 6; Fig. 8B-8E). Mean depolarizations were $4.1 \pm 0.7 \mathrm{mV}(\mathrm{n}=6)$ for Y-27632, $4.6 \pm 1.0 \mathrm{mV}$ $(\mathrm{n}=6)$ for SC-560, $4.2 \pm 0.8 \mathrm{mV}(\mathrm{n}=6)$ for NS-398, $0.8 \pm 0.7 \mathrm{mV}(\mathrm{n}=5)$ for ozagrel and $1.6 \pm$ 


\section{Cellular Physiology Cell Physiol Biochem 2016;38:1869-1882

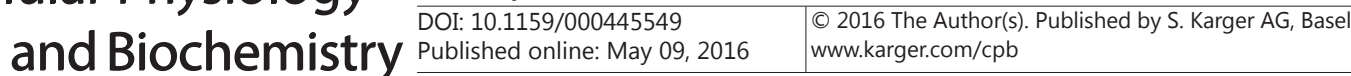 \\ Kim et al.: Effects of Menthol in ICCs}

$0.5 \mathrm{mV}(\mathrm{n}=6)$ for SQ-29548 (Fig. 8F). These results suggest that Rho-kinase, COX pathways, and thromboxane $\mathrm{A} 2$ are involved in menthol-induced membrane potential depolarization.

\section{Discussion}

Menthol is a major constituent of peppermint (Mentha piperita L) oil and of the herbal preparations commonly used in traditional medicine to treat various GI disorders. In the scientific literature, peppermint oil was reported to be an effective treatment for nausea and vomiting [10], and its intraluminal administration was found to be a simple, safe, and convenient alternative for the prevention and amelioration of colonic spasms caused by endoscopy $[44,45]$. In addition, peppermint oil has been used to treat irritable bowel disease [46]. Menthol has been reported to reduce gastric emptying rates in vivo, to relax whole stomach in vitro in mice [47], to relax intestinal and colonic muscle strips [48, 49], and to reduce small intestine motility [12]. However, Rogers et al. [50] suggested that peppermint oil increased colonic contraction with spasm. To date, these experiments are achieved mainly smooth muscle cells or muscle strips and the action and pathways mediating the effects of peppermint oil or menthol-containing products in GI tract remain controversial. GI motility patterns are highly integrated behaviours requiring coordination between smooth muscle cells and utilizing regulatory inputs from ICCs, neurons, and endocrine and immune cells [51]. However, the regulatory effects of menthol on ICC pacemaker potentials and mechanisms responsible have not been elucidated. For this reason, in this study, we was designed to investigate the receptors and signal pathways responsible for mediating the effects of menthol in cultured ICCs from murine small intestine.

Rho-kinase is a target molecule of RhoA, a small G protein that plays an important role in cell membrane signal transduction pathways, and the Rho-kinase pathway has been suggested to play a role in smooth muscle contraction [52]. Rho kinase is expressed in ICCs [53] and Mustafa et al. [54] reported that administration of menthol caused rat fundus contraction that was associated with the Rho kinase pathway. Also, TRPA1 can activate Rhokinase to phosphorylate myosin light chain, ultimately lead to vasoconstriction in the mouse [36]. To investigate the involvement of Rho-kinase in menthol-induced membrane potential depolarization in ICCs, we used Y-27632, an inhibitor of Rho-kinase. Y-27632 treatment had no effect on PPs and in the presence of Y-27632, menthol-induced membrane potential depolarization was blocked (Fig. 8). These findings suggest Rho-kinase participates in the menthol-induced membrane potential depolarization. COX is a membrane-bound functional enzyme that transforms arachidonic acid to the intermediate prostaglandin (PG) H2, which is then converted to prostanoids by specific synthases [55]. At least two distinct COX isoforms have been identified, namely COX-1 and COX-2 [56]. In isolated strips of rabbit bladder, it was previously concluded both COX isozymes participate in the spontaneous rhythmic contractions of ICCs [57]. Also, several papers have reported the involvement of COX and prostaglandins (PG) in menthol or TRPA1-induced effects [38, 39, 58, 59]. Furthermore, PG are generated through the activity of COX and play a significant role in its physiology in the GI tract [60]. In particular, PG are widely distributed in the GI tract and thromboxane A2 (TXA2) can regulate intestinal motility by modulating the pacemaker activities of ICCs [61]. In the present study, we think that these all pathways maybe involve in menthol-induced effects and all inhibitors involved in these pathways block menthol-induced effects and found the menthol-induced membrane potential depolarization was blocked by COX and TXA2 inhibitors and, indicating that the production of PG is involved in stimulating menthol effects (Fig. 8).

Peppermint oil and menthol act at many molecular sites and are known to initiate several pathways $[41,62,63]$. In the intestinal tract, the various pharmacological effects of peppermint oil have been reported to involve $\mathrm{Ca}^{2+}$-channel [11], and in the GI tract, its effects have been associated with TRPM8 channel (a nonselective cation channel gated by cold stimuli) and its menthol content. TRPM8 channels are expressed in rat gastric and colonic 
muscles [64], in mouse small and large intestine mucosa and myenteric plexus [6, 65], and in human colon muscles [6]. Menthol has also been reported to be able to modulate TRPA1 ion channels [4]. In the present study, a TRPM8 antagonist (AMTB) did not block mentholinduced membrane potential depolarization, whereas TRPA1 antagonists (A967079 or HC030031) did (Fig. 2). Furthermore, TRPA1 protein was found to be localized in ICCs (Fig. 4), suggesting menthol depolarized PPs via TRPA1 receptor. Also, it has been known that TRPA1 interacts with G-protein-coupled receptors [66]. Therefore, we decided to test for G-protein involvement in menthol response (Fig. 5). In these experiments, when GDP ${ }_{\beta} \mathrm{S}$ was present in the pipette, the membrane potential depolarization by menthol was suppressed. This means that TRPA1 channels are coupled with G-proteins in ICCs.

External $\mathrm{Ca}^{2+}$ influx and intracellular $\mathrm{Ca}^{2+}$ oscillations are required to generate PPs by ICCs [34]. In the presence of an external $\mathrm{Ca}^{2+}$-free solution, pacemaking activity was completely abolished, and menthol did not depolarize PPs (Fig. 6). In addition, in the presence of thapsigargin, pacemaking activity was also completely abolished and menthol did not depolarize PPs (Fig. 6). We think that both external $\mathrm{Ca}^{2+}$ influx and internal $\mathrm{Ca}^{2+}$ release from endoplasmic reticulum are important in the menthol-induced membrane potential depolarization. We do not know which one prevails. In future, we will investigate intracellular $\mathrm{Ca}^{2+}$ concentration in each conditions. After that, we can understand which one prevails. In addition, emptying of intracellular $\mathrm{Ca}^{2+}$ stores by thapsigargin increased intracellular $\mathrm{Ca}^{2+}$ concentration [67]. Therefore, in the present study, thapsigargin maybe increase intracellular $\mathrm{Ca}^{2+}$ concentration and induce membrane potential depolarization (Fig. 6).

Intestinal motility depends on the intrinsic contractility of the circular and longitudinal smooth muscle layers and a superordinate coordination which is provided by the enteric nervous system (ENS). The ENS can be deactivated using TTX [68] and as reviewed by Lee et al. [69], TTX is a potent neurotoxin which binds to voltage-gated $\mathrm{Na}^{+}$channels, inhibiting the initiation and propagation of action potentials in GI tract. In previous studies, by blocking the ENS using TTX, lidocaine induced contractility effects at the level of smooth muscle cells and/or ICCs [70, 71]. Also, $\mathrm{Na}(\mathrm{v}) 1.2, \mathrm{Na}(\mathrm{v}) 1.3$, and $\mathrm{Na}(\mathrm{v}) 1.6$, and possibly $\mathrm{Na}(\mathrm{v}) 1.7$, are the TTX-sensitive sodium channels expressed in the enteric nervous system [72, 73]. Therefore, TTX-sensitive sodium channels might be ubiquitous in the enteric nervous system, smooth muscle cells and ICCs of the GI tract. In the present study, TTX had no effect on PPs and under these conditions, menthol induced membrane potential depolarization (Fig. 7). Also, in the presence of external $\mathrm{Na}^{+} 5 \mathrm{mM}$ solution, PPs were abolished, and under these conditions, menthol $(10 \mu \mathrm{M})$ induced membrane potential depolarization (Fig. 7). Therefore, external $\mathrm{Na}^{+}$is not an important driver of menthol-induced membrane potential depolarization.

Slow waves play an important role in the regulation of GI motility by determining the frequency and timing of smooth muscle contractions, and ICCs, which are connected to smooth muscle cells by gap junctions to form a network, are the pacemaker cells that generate slow waves by producing spontaneous PPs. Accordingly, PPs generated by ICCs are directly transmitted to smooth muscles through gap junctions [13-15]. In addition, ICCs mediate inhibitory and excitatory signals from the enteric nervous system to smooth muscles, and thus, importantly regulate GI motility. Furthermore, it has been reported ICCs express muscarinic, adrenergic, tachykinin, somatostatin, and purinergic receptors, which strongly suggests they are targeted by a variety of endogenous and exogenous substances [22]. In the present study, TRPA1 antagonist did not cause any change on both pacemaking activity and membrane potential (Fig. 2), suggests that the TRPA1 channel is not participating in PP or in maintaining resting membrane potential in ICCs. Instead, our finding that TRPA 1 is a cation channel involved in the menthol-induced membrane potential depolarization in the pacemaking activity of ICCs from the murine small intestine. It has been known that TRPM7 and ANO1 is responsible for the PP in ICCs [24-27].

In this study, we focused on the roles of menthol and of its TRPA1 receptors in ICCs from murine small intestine. We believe our findings substantially expand knowledge of the roles and signal pathways of menthol in cultured ICCs and of the physiological 


\section{Cellular Physiology Cell Physiol Biochem 2016;38:1869-1882

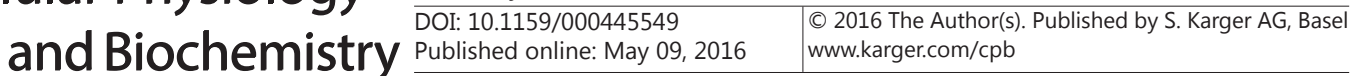 \\ Kim et al.: Effects of Menthol in ICCs}

and pathophysiological roles of menthol signaling. In particular, menthol was found to induce membrane potential depolarization in a G-protein-, $\mathrm{Ca}^{2+}{ }^{2}$, Rho-kinase-, COX-, and thromboxane $\mathrm{A}_{2}$ dependent manner via TRPA1 receptor, which may explain the excitatory effect of menthol on GI motility.

\section{Acknowledgements}

This work was supported by a National Research Foundation of Korea (NRF) grant funded by the Korean government (MSIP) (\#2014R1A5A2009936).

\section{Disclosure Statement}

The authors have no disclosures.

\section{References}

1 Eccles R: Menthol and related cooling compounds. J Pharm Pharmacol 1994;46:618-630.

2 Journigan VB, Zaveri NT: TRPM8 ion channel ligands for new therapeutic applications and as probes to study menthol pharmacology. Life Sci 2013;92:425-437.

3 McKemy DD, Neuhausser WM, Julius D: Identification of a cold receptor reveals a general role for TRP channels in thermosensation. Nature 2002;416:52-58.

4 Karashima Y, Damann N, Prenen J, Talavera K, Segal A, Voets T, Nilius B: Bimodal action of menthol on the transient receptor potential channel TRPA1. J Neurosci 2007;27:9874-9884.

5 Mustafa S, Oriowo M: Cooling-induced contraction of the rat gastric fundus: mediation via transient receptor potential (TRP) cation channel TRPM8 receptor and Rho-kinase activation. Clin Exp Pharmacol Physiol 2005;32:832-838.

6 Ramachandran R, Hyun E, Zhao L, Lapointe TK, Chapman K, Hirota CL, Ghosh S, McKemy DD, Vergnolle N, Beck PL, Altier C, Hollenberg MD: TRPM8 activation attenuates inflammatory responses in mouse models of colitis. Proc Natl Acad Sci 2013;110:7476-7481.

7 Holzer P: TRP channels in the digestive system. Curr Pharm Biotechnol 2011;12:24-34.

8 Poole DP, Pelayo JC, Cattaruzza F, Kuo YM, Gai G, Chiu JV, Bron R, Furness JB, Grady EF, Bunnett NW: Transient receptor potential Ankyrin 1 is expressed by inhibitory motoneurons of the mouse intestine. Gastroenterology 2011;141:565-575.

9 Westfall RE: Use of antiemetic herbs in pregnancy: women's choices, and the question of safety and efficacy. Compl Ther Nurs Midwifery 2004;10:30-36.

10 Haniadka R, Popouri S, Palatty PL, Arora R, Baliga MS: Medicinal plants as antiemetics in the treatment of cancer: a review. Integr Cancer Ther 2012;11:18-28.

11 Grigoleit HG, Grigoleit P: Pharmacology and preclinical pharmacokinetics of peppermint oil. Phytomedicine 2005;12:612-616.

12 McKay DL, Blumberg JB: A review of the bioactivity and potential health benefits of peppermint tea (Mentha piperita L.). Phytother Res 2006;20:619-633.

13 Hagger R, Gharaie S, Finlayson C, Kumar D: Distribution of the interstitial cells of Cajal in the human anorectum. J Auton Nerv Syst 1998;73:75-79.

14 Gim H, Nam JH, Lee S, Shim JH, Kim HJ, Ha KT, Kim BJ: Quercetin Inhibits Pacemaker Potentials via Nitric Oxide/cGMP-Dependent Activation and TRPM7/ANO1 Channels in Cultured Interstitial Cells of Cajal from Mouse Small Intestine. Cell Physiol Biochem 2015;35:2422-2436.

15 Kim BJ, Nam JH, Kim KH, Joo M, Ha TS, Weon KY, Choi S, Jun JY, Park EJ, Wie J, So I, Nah SY: Characteristics of gintonin-mediated membrane depolarization of pacemaker activity in cultured interstitial cells of Cajal. Cell Physiol Biochem 2014;34:873-890. 


\section{Cellular Physiology Cell Physiol Biochem 2016;38:1869-1882 \begin{tabular}{l|l|} 
and BOI: 10.1159/000445549 & $\begin{array}{l}\text { C) 2016 The Author(s). Published by S. Karger AG, Basel } \\
\text { www.karger.com/cpb }\end{array}$
\end{tabular} \\ Kim et al.: Effects of Menthol in ICCs}

16 Ward SM, Burns AJ, Torihashi S, Sanders KM: Mutation of the proto-oncogene c-kit blocks development of interstitial cells and electrical rhythmicity in murine intestine. J Physiol 1994;480:91-102.

17 Huizinga JD, Thuneberg L, Klüppel M, Malysz J, Mikkelsen HB, Bernstein A: W/kit gene required for interstitial cells of Cajal and for intestinal pacemaker activity. Nature 1995;373:347-349.

18 Sanders KM: A case for interstitial cells of Cajal as pacemakers and mediators of neurotransmission in the gastrointestinal tract. Gastroenterology 1996;111:492-515.

19 Maeda H, Yamagata A, Nishikawa S, Yoshinaga K, Kobayashi S, Nishi K, Nishikawa S: Requirement of c-kit for development of intestinal pacemaker system. Development 1992;116:369-375.

20 Gomez-Pinilla PJ, Gibbons SJ, Bardsley MR, Lorincz A, Pozo MJ, Pasricha PJ Van de Rijn M, West RB, Sarr MG, Kendrick ML, Cima RR, Dozois EJ, Larson DW, Ordog T, Farrugia G: Ano1 is a selective marker of interstitial cells of Cajal in the human and mouse gastrointestinal tract. Am J Physiol Gastrointest Liver Physiol 2009;296:G1370-G1381.

21 Koh SD, Jun JY, Kim TW, Sanders KM: A Ca2+-inhibited non-selective cation conductance contributes to pacemaker currents in mouse interstitial cell of Cajal. J Physiol 2002;540:803-814.

22 Kim BJ, So I, Kim KW: The relationship of TRP channels to the pacemaker activity of interstitial cells of Cajal in the gastrointestinal tract. J Smooth Muscle Res 2006;42:1-7.

23 Huizinga JD, Zhu Y, Ye J, Molleman A: High conductance chloride channels generate pacemaker currents in interstitial cells of Cajal. Gastroenterology 2002;123:1627-1636.

24 Zhu MH, Kim TW, Ro S, Yan W, Ward SM, Koh SD, Sanders KM: A Ca2+-activated Cl-conductance in interstitial cells of Cajal linked to slow wave currents and pacemaker activity. J Physiol 2009;587:49054918.

25 Kim BJ, Lim HH, Yang DK, Jun JY, Chang IY, Park CS, So I, Stanfield PR, Kim KW: Melastatin-Type Transient Receptor Potential Channel 7 Is Required for Intestinal Pacemaking Activity. Gastroenterology 2005;129:1504-1517.

26 Huang F, Rock JR, Harfe BD, Cheng T, Huang X, Jan YN, Jan LY: Studies on expression and function of the TMEM16A calcium-activated chloride channel. Proc Natl Acad Sci U S A 2009;106:21413-21418.

27 Sanders KM, Zhu MH, Britton F, Koh SD, Ward SM: Anoctamins and gastrointestinal smooth muscle excitability. Exp Physiol 2012;97:200-206.

28 Lee JH, Kim SY, Kwon YK, Kim BJ, So I: Characteristics of the cholecystokinin-induced depolarization of pacemaking activity in cultured interstitial cells of Cajal from murine small intestine. Cell Physiol Biochem 2013;31:542-554.

29 Goto K, Matsuoka S, Noma A: Two types of spontaneous depolarizations in the interstitial cells freshly prepared from the murine small intestine. J Physiol 2004;559:411-422.

30 Peier AM, Moqrich A, Hergarden AC, Reeve AJ, Andersson DA, Story GM, Earley TJ, Dragoni I, McIntyre P, Bevan S, Patapoutian A: A TRP channel that senses cold stimuli and menthol. Cell 2002;108:705-715.

31 Lashinger ES, Steiginga MS, Hieble JP, Leon LA, Gardner SD, Nagilla R, Davenport EA, Hoffman BE, Laping NJ, Su X: AMTB, a TRPM8 channel blocker: evidence in rats for activity in overactive bladder and painful bladder syndrome. Am J Physiol Renal Physiol 2008;295:F803-F810.

32 Komori S, Kawai M, Takewaki T, Ohashi H: GTP-binding protein involvement in membrane currents evoked by carbachol and histamine in guinea-pig ileal muscle. J Physiol 1992;450:105-126.

33 Ogata R, Inoue Y, Nakano H, Ito Y, Kitamura K: Oestradiol-induced relaxation of rabbit basilar artery by inhibition of voltage-dependent Ca channels through GTP-binding protein. Br J Pharmacol 1996;117:351359.

34 Ward SM, Ordog T, Koh SD, Baker SA, Jun JY, Amberg G, Monaghan K, Sanders KM: Pacemaking in interstitial cells of Cajal depends upon calcium handling by endoplasmic reticulum and mitochondria. J Physiol 2000;525:355-361.

35 Koh SD, Jun JY, Kim TW, Sanders KM: A Ca2+-inhibited non-selective cation conductance contributes to pacemaker currents in mouse interstitial cell of Cajal. J Physiol 2002;540:803-814.

36 Choi S, Choi JJ, Jun JY, Koh JW, Kim SH, Kim DH, Pyo MY, Choi S, Son JP, Lee I, Son M, Jin M: Induction of pacemaker currents by DA-9701, a prokinetic agent, in interstitial cells of Cajal from murine small intestine. Mol Cells 2009;27:307-312.

37 Aubdool AA, Graepel R, Kodji X, Alawi KM, Bodkin JV, Srivastava S, Gentry C, Heads R, Grant AD, Fernandes ES, Bevan S, Brain SD: TRPA1 is essential for the vascular response to environmental cold exposure. Nat Commun 2014;5:5732. 


\section{Cellular Physiology Cell Physiol Biochem 2016;38:1869-1882 \begin{tabular}{l|l} 
DOI: 10.1159/000445549 & $\begin{array}{l}\text { O 2016 The Author(s). Published by S. Karger AG, Basel } \\
\text { www.karger.com/cpb }\end{array}$
\end{tabular} \\ Kim et al.: Effects of Menthol in ICCs}

38 Somlyo AP, Somlyo AV: Ca2+ sensitivity of smooth muscle and nonmuscle myosin II: modulated by G proteins, kinases, and myosin phosphatase. Physiol Rev 2003;83:1325-1358.

39 Andrade EL, Ferreira J, Andre E, Calixto JB: Contractile mechanisms coupled to TRPA1 receptor activation in rat urinary bladder. Biochem Pharmacol 2006;72:104-114.

40 Bautista DM, Jordt SE, Nikai T, Tsuruda PR, Read AJ, Poblete J, Yamoah EN, Basbaum AI, Julius D: TRPA1 mediates the inflammatory actions of environmental irritants and proalgesic agents. Cell 2006;124:12691282.

41 Trandafir CC, Pouliot WA, Dudek FE, Ekstrand JJ: Co-administration of subtherapeutic diazepam enhances neuroprotective effect of COX-2 inhibitor, NS-398, after lithium pilocarpine-induced status epilepticus. Neuroscience 2015;284:601-610.

42 Tomishima Y, Ishitsuka Y, Matsunaga N, Nagatome M, Furusho H, Irikura M, Ohdo S, Irie T: Ozagrel hydrochloride, a selective thromboxane $\mathrm{A}_{2}$ synthase inhibitor, alleviates liver injury induced by acetaminophen overdose in mice. BMC Gastroenterol 2013;13:21.

43 Uchiyama K, Saito M, Sasaki M, Obara Y, Higashiyama S, Nakahata N: Thromboxane A2 receptor-mediated epidermal growth factor receptor transactivation: involvement of PKC-delta and PKC-epsilon in the shedding of epidermal growth factor receptor ligands. Eur J Pharm Sci 2009;38:504-511.

44 Asao T, Mochiki E, Suzuki H, Nakamura J, Hirayama I, Morinaga N, Shoji H, Shitara Y, Kuwano H: An easy method for the intraluminal administration of peppermint oil before colonscopy and its effectiveness in reducing colonic spasm. Gastrointest Endosc 2001;53:172-177.

45 Yoshida N, Naito Y, Hirose R, Ogiso K, Inada Y, Fernandopulle N, Kamada K, Katada K, Uchiyama K, Handa O, Takagi T, Konishi H, Yagi N, Wakabayashi N, Yanagisawa A, Itoh Y: Prevention of colonic spasm using L-menthol in colonoscopic examination. Int J Colorectal Dis 2014;29:579-583.

46 Ford AC, Talley NJ, Spiegel BM, Foxx-Orenstein AE, Schiller L, Quigley EM, Moayyedi P: Effect of fibre, antispasmodics, and peppermint oil in the treatment of irritable bowel syndrome: systematic review and meta-analysis. Br Med J 2008;337:a2313.

47 Amato A, Liotta R, Mulè F: Effects of menthol on circular smooth muscle of human colon: analysis of the mechanism of action. Eur J Pharmacol 2014;740:295-301.

48 Mahmood SA, Abbas NA, Rojas RL: Effects of aqueous extracts of peppermint, fennel, dill and cuminon isolated rabbit duodenum. J Nat Appl Sci 2003;7:377-383.

49 Penuelas A, Tashima K, Tsuchiya S, Matsumoto K, Nakamura T, Horie S, Yano S: Contractile effect of TRPA1 receptor agonists in the isolated mouse intestine. Eur J Pharmacol 2007;8:143-150.

50 Rogers J, Tay HH, Misiewicz JJ: Peppermint oil. Lancet 1988;2:98-99.

51 Sanders KM, Koh SD, Ro S, Ward SM: Regulation of gastrointestinal motility--insights from smooth muscle biology. Nat Rev Gastroenterol Hepatol 2012;9:633-645.

52 Webb RC: Smooth muscle contraction and relaxation. Adv Physiol Educ 2003;27:201-206.

53 Coyle D, O'Donnell AM, Corcionivoschi N, Gillick J, Puri P: Rho-kinase expression in Hirschsprung's disease. Pediatr Surg Int 2015;31:1077-1085.

54 Mustafa S, Oriowo M: Cooling-induced contraction of the rat gastric fundus: mediation via transient receptor potential (TRP) cation channel TRPM8 receptor and Rho-kinase activation. Clin Exp Pharmacol Physiol 2005;32:832-838.

55 Needleman P, Moncada S, Bunting S, Vane JR, Hamberg M, Samuelsson B: Identification of an enzyme in platelet microsomes which generates thromboxane A2 from prostaglandin endoperoxides. Nature 1976;261:558-560.

56 Clària J: Cyclooxygenase-2 biology. Curr Pharm Des 2003;9:2177-2190.

57 Collins C, Klausner AP, Herrick B, Koo HP, Miner AS, Henderson SC, Ratz PH: Potential for control of detrusor smooth muscle spontaneous rhythmic contraction by cyclooxygenase products released by interstitial cells of Cajal. J Cell Mol Med 2009;13:3236-3250.

58 Ott D, Simm B, Pollatzek E, Gerstberger R, Rummel C, Roth J: Prostaglandin D2 modulates calcium signals induced by prostaglandin E2 in neurons of rat dorsal root ganglia. Neurosci Lett 2015;597:159-163.

59 Liu Z, Shen C, Tao Y, Wang S, Wei Z, Cao Y, Wu H, Fan F, Lin C, Shan Y, Zhu P, Sun L, Chen C, Wang A, Zheng S, Lu Y: Chemopreventive efficacy of menthol on carcinogen-induced cutaneous carcinoma through inhibition of inflammation and oxidative stress in mice. Food Chem Toxicol 2015;82:12-18. 


\section{Cellular Physiology Cell Physiol Biochem 2016;38:1869-1882 \begin{tabular}{ll|l} 
DOI: 10.1159/000445549 & $\begin{array}{l}\text { O 2016 The Author(s). Published by S. Karger AG, Basel } \\
\text { www.karger.com/cpb }\end{array}$ \\
\cline { 2 - 3 } & Published online: May 09, 2016 &
\end{tabular} \\ Kim et al.: Effects of Menthol in ICCs}

60 Whittle BJR, Vane JR: Prostanoids regulators of gastrointestinal function: in Physiology of Gastrointestinal Tract, Johnson LR (ed): New York, Raven Press, 1987, pp 143-276.

61 Kim JH, Choi SJ, Yeum CH, Yoon PJ, Choi S, Jun JY: Involvement of thromboxane a(2) in the modulation of pacemaker activity of interstitial cells of cajal of mouse intestine. Korean J Physiol Pharmacol 2008;12:2530.

62 Hills JM, Aaronson PI: The mechanism of action of peppermint oil on gastrointestinal smooth muscle. Ananalysis using patch clamp electrophysiology and isolated tissue pharmacology in rabbit and guinea pig. Gastroenterology 1991;101:65-75.

63 De Araújo DA, Freitas C, Cruz JS: Essential oils components as a new path to understand ion channel molecular pharmacology. Life Sci 2011;89:540-544.

64 Mustafa S, Oriowo M: Cooling-induced contraction of the rat gastric fundus: mediation via transient receptor potential (TRP) cation channel TRPM8 receptor and Rho-kinase activation. Clin Exp Pharmacol Physiol 2005;32:832-838.

65 Zhang L, Jones S, Brody K, Costa M, Brookes SJ: Thermosensitive transient receptor potential channels in vagal afferent neurons of the mouse. Am J Physiol Gastrointest Liver Physiol 2004;286:G983-G991.

66 Brierley SM, Hughes PA, Page AJ, Kwan KY, Martin CM, O'Donnell TA, Cooper NJ, Harrington AM, Adam B, Liebregts T, Holtmann G, Corey DP, Rychkov GY, Blackshaw LA: The ion channel TRPA1 is required for normal mechanosensation and is modulated by algesic stimuli. Gastroenterology 2009;137:2084-2095.

67 Gong YY, Si XM, Lin L, Lu J: Mechanisms of cholecystokinin-induced calcium mobilization in gastric antral interstitial cells of Cajal. World J Gastroenterol 2012;18:7184-7193.

68 Boddy G, Bong A, Cho W, Daniel EE: ICC pacing mechanisms in intact mouse intestine differ from those in cultured or dissected intestine. Am J Physiol Gastrointest Liver Physiol 2004;286:G653-G662.

69 Lee CH, Ruben PC: Interaction between voltage-gated sodium channels and the neurotoxin, tetrodotoxin. Channels 2008;2:407-412.

70 Guschlbauer M, Hoppe S, Geburek F, Feige K, Huber K: In vitro effects of lidocaine on the contractility of equine jejunal smooth muscle challenged by ischaemia-reperfusion injury. Equine Vet J 2010;42:53-58.

71 Tappenbeck K, Hoppe S, Reichert C, Feige K, Huber K: In vitro effects of lidocaine on contractility of circular and longitudinal equine intestinal smooth muscle. Vet J 2013;198:170-175.

72 Bartoo AC, Sprunger LK, Schneider DA: Expression and distribution of TTX-sensitive sodium channel alpha subunits in the enteric nervous system. J Comp Neurol 2005;486:117-131.

73 Sage D, Salin P, Alcaraz G, Castets F, Giraud P, Crest M, Mazet B, Clerc N: Na(v)1.7 and Na(v)1.3 are the only tetrodotoxin-sensitive sodium channels expressed by the adult guinea pig enteric nervous system. J Comp Neurol 2007;504:363-378. 